\title{
Case Study: Structured Settlements
}

Sheldon Epstein, (E-mail: epsteish@shu,edu), Seton Hall University

Bernard Dickman, (E-mail: acsbhd@mail.hofstra.edu), Hofstra University

Yonah Wilamowsky, (E-mail: wilamoyo.shu.edu), Seton Hall University

\begin{abstract}
Students are presented with a report that offers a present value analysis of a Structured Settlement and asked to decide whether they agree with its conclusions. The case tests quantitative, financial and spreadsheet skills, exposes students to the world of law and legal statutes, and requires value judgments about fairness. The case is appropriate for senior-level undergraduate business majors and $M B A s$, in courses that involve decision-making.
\end{abstract}

\section{BACKGROUND}

\begin{abstract}
C negligence lawsuits in which the plaintiff prevails it is common to have the jury's award paid out in the form of a Structured Settlement. In this situation, rather than the plaintiff receiving a lump sum payment at the conclusion of the trial, the plaintiff receives at least part of the payment in the form of an annuity to be paid out over a multiyear period. It is also common in negligence cases for the plaintiff's attorney to accept the case on a contingency basis whereby the attorney receives nothing if the plaintiff loses but receives a percentage of the settlement if the plaintiff prevails. While the plaintiff receives payments over a multi-year period in the case of a Structured Settlement, the plaintiff's attorney is paid in full at the completion of the trial. Since there is a time value associated with money, i.e. money paid in the future is worth less than money received today, the question arises as to how to calculate the present value of the plaintiff's annuity and the attorney's remuneration.
\end{abstract}

In New York State, the legally mandated methodology for computing all of the components of a Structured Settlement is given in NY Statute 50A (See attached Document 1). In general terms, Statute 50A differentiates between:

- $\quad$ Damages the plaintiff has already incurred. Damages due to either pain \& suffering, or lost earnings, are to be paid in one lump sum as of the date of the jury verdict.

- Damages the plaintiff will incur in the future because of the defendant's negligence

i) Consideration of future pain \& suffering is limited to a maximum of 10 years.

ii) Consideration of future lost earnings has no legally imposed time limit.

iii) The first $\$ 250,000$ of future damages is to be paid in one lump sum as of the date of the jury verdict. This $\$ 250,000$ is to be allocated to pain \& suffering and lost earnings in the same proportion each has in the overall future damages

iv) Future damages in excess of $\$ 250,000$ are to be paid out over the period of time that they will be incurred. The first year's payment for pain \& suffering is the remaining unpaid part of the total future pain \& suffering divided by the number of years (up to the limit of 10) that the plaintiff will endure pain \& suffering. The first year's payment for lost earnings is the remaining unpaid part of the total future lost earnings divided by the number of years that the plaintiff will endure lost earnings. Payments for every succeeding year for both are to be increased by $4 \%$ 
v) Payment for future pain \& suffering ceases upon the death of the plaintiff.

After all of the above calculations are completed, Statute 50A requires the computation of the present value of the periodic future payments using an appropriate discount rate. Combining the present value of future payments with the required lump sum payments as of the date of the verdict yields the overall present value of the settlement. Remuneration for the plaintiff's attorney is: $30 \%$ of the first $\$ 250,000$ of present value, $25 \%$ for the next $\$ 250,000$, $20 \%$ for the next $\$ 500,000,15 \%$ for the next $\$ 250,000$ and $10 \%$ for the remainder.

The above explanation of Statute 50A involves a number of interpretations of ambiguous parts of the Statute. These interpretations have at times been challenged in Court and the resulting Court opinions are a matter of judicial record ${ }^{1}$.

\section{BARRY LARKE V. BOOT HILL MEMORIAL CENTER}

On the next page is a report prepared for a plaintiff's attorney by a leading Structured Settlement firm in the case of Barry Larke v. Boot Hill Memorial Center ${ }^{2}$. This document contains a present value analysis of a Structured Settlement where the total jury award was in excess of $\$ 2,000,000$ and included payments for pain \& suffering, and loss of earning:

- $\quad$ That were to be made immediately,

- To be paid monthly over a 10 year period,

- $\quad$ To be paid monthly over a 25 year period.

The report reviews the N.Y. State Statute on Structured Settlements and, based on that Statute, offers numerical values for how much the plaintiff and the plaintiff's attorney will receive immediately, and how much the plaintiff will receive monthly over the next 25 years. The report includes a spreadsheet printout explaining how all of the figures were derived.

After reviewing the report, the plaintiff's attorney questioned some of the items in the report, including:

- $\quad$ The use of $4.1 \%$ and $5.18 \%$ discount rate for the 10 year and 25 year payout periods respectively- The $4.1 \%$ and $5.18 \%$ rates were respectively the rates of 10 year and 25 year US Government Treasury instruments. Plaintiff's attorney felt that these numbers were inappropriate because monies received in the early years of the payout could not utilize the higher interest rates offered by longer term government instruments..

- $\quad$ The calculation that the present value of future damages for pain \& suffering of $\$ 493,314$ was $\$ 477,853$ By law the monthly payments were to increase by $4 \%$ per year. Since the interest rate for the 10 year period was only $4.1 \%$, plaintiff's lawyer argued that the present value should intuitively show little change. Yet, in the spreadsheet analysis the present value decreased by more than $\$ 15,000$.

Please read the expert's report carefully and then address the issues raised in the Assignment section that immediately follows the report.

\footnotetext{
${ }^{1}$ e.g. Samuel Desiderio, \& c. v. Dr. Robert L. Ochs, et al.

${ }^{2}$ The names, addresses etc of the expert, plaintiff and defendant have been changed. Everything else is exactly as originally written.
} 


\title{
BlackJack Century Group Analytical Specialists "We Make Sure You Hit the Jackpot"
}

\author{
3540 West $53^{\text {rd }}$ Street \\ New York, NY 10000 \\ 212/555-3000
}

July 29, 2003

James Smith, Esq.

Homer, Wyatt \& Brown, LLP

163.5 Fifth Avenue

New York, NY 10001

Re: $\quad$ Barry Larke v. Boot Hill Memorial Center

Dear Mr. Smith:

Thank you for referring this matter to our office. It is our understanding that on December 17, 2002, a verdict was returned in the amount of $\$ 2,056,000.00$.

Please be advised that we were consultants on 6 of the 7 landmark Appellate Court decisions in New York State, the most recent being Parker.

Since this case was filed after July 1, 1985, it is therefore subject to the N.Y. State Periodic Payment Act Article 50A. The law directs that on all verdicts where future damages are in excess of $\$ 250,000$, the defendants and their insurers are required to offer and guarantee the purchase and payment of an annuity contract approved by the Superintendent of Insurance. This must be accomplished within thirty (30) days of judgment.

After verdict, the first $\$ 250,000$ of future damages is proportionately deducted from the itemized verdict. This amount, as well as past damages, is payable in a lump sum. All remaining future damages are then annuitized. The jury determines the period of time over which payments are made. Damages are then divided by said years resulting in an annualized award, which is paid monthly. All benefits must compound at $4 \%$ per annum.

Awards for future damages terminate upon death and are not guaranteed. The only exception is future earnings. Should death occur, all remaining payments must be paid to the person(s) for the determined period of time that support was owed.

Future Pain \& Suffering is no more than 10 years or the period of time determined by the jury whichever, is less. Should a shorter period of time be found, the award is divided by said number of years.

Please note that under Article 50A, attorney fees are calculated in accordance with the sliding scale as follows:

$30 \%$ of the first $\$ 250,000$

$25 \%$ of the next $\$ 250,000$

$20 \%$ of the next $\$ 500,000$

$15 \%$ of the next $\$ 250,000$

$10 \%$ of everything above
$\$ 75,000$

$\$ 62,500$

$\$ 100,000$

$\$ 37,500$

$\$ 1,250,000$ 
The present value was calculated using the following discount rates in effect on the date of verdict:

Pain \& Suffering: $\quad 10$ year bond at $4.10 \%$

Loss of Earnings: $\quad 25$ year bond at $5.18 \%$

The present value judgment is $\$ 1,944,065.12$, not including interest.

Attached is the Worksheet Summary to satisfy the verdict. All annuity payments are calculated, as of the date of the verdict, December 17, 2002. Annuity payments in arrears are paid in a lump sum, pursuant to the Second Department's recent decisions Brown v. NYC and Scannapieco v. NYC.

We have calculated the annuity payments in arrears from the date of verdict, 12/17/2002 thru the present, 09/17/2003 (10 payments). After making the required adjustments to the verdict in accordance with Article 50A, we have calculated the benefits for Barry (see attached worksheet summary).

Attached herewith please find our matrix spreadsheet and a reference guide explaining how we arrived at our calculations.

In closing, should you have any questions, or if we can be of any further assistance, please do not hesitate to contact this office. Thank you for your courtesy and the opportunity to be of service. We await your further advice.

Very truly yours,

Gretchen L. Beeks

Executive Vice President

-- End of Letter --

Enclosures

Worksheet Summary For Barry Larke Date Of Verdict: 12/17/2002

Attorney Fees:

Litigation Expenses:

Lump Sum Cash To Pltf:

Annuity Payments In Arrears To Be Paid In Cash

For The Period (12/17/02-09/17/03)
$\$ 344,406.51$

$\$ 0.00$

$\$ 740,557.88$

$\$ 52,002.86$

Future Pain \& Suffering To Be Paid As Follows:

\$40,591.98 Per Year For 10 Years Temp. Comp. Ann. @ 4\% Commencing 12/17/2002-11/17/2012: Projected Payout: $\$ 487,351.66$

$\begin{array}{lcccc}\text { Cash: } & 12 / 17 / 02-09 / 17 / 03 & 10 \text { MOS. } & \frac{\text { Mo. Benefit }}{\$ 3,382.66} & \text { Projected } \\ \text { Annuity: } & 10 / 17 / 03-11 / 17 / 03 & 2 \text { MOS. } & \$ 3,3826.66 \\ & 12 / 17 / 03-11 / 17 / 12 & 9 \text { YRS. } & \$ 3,517.97 \text { Comp @ } 4 & \$ 33,826.66 \\ & & & & \$ 6,765.32 \\ & & & & \$ 453,759.68 \\ & & & & \$ 487,351.66\end{array}$




\section{Future Loss Of Earnings To Be Paid As Follows:}

\$21,811.43 Per Year For 25 Years Temp. Comp. Ann. @ 4\% Commencing 12/17/2002-11/17/27. Projected Payout: \$908,356.81

$\begin{array}{lcccc}\text { Cash: } & & & \text { Mo. Benefit } & \text { Projected } \\ & 12 / 17 / 02-09 / 17 / 03 & 10 \text { Mos. } & \$ 1,817.62 & \$ 18,176.20 \\ \text { Annuity: } & & & & \\ & & & & \\ & 10 / 17 / 03-11 / 17 / 03 & 2 \text { Mos. } & \$ 1,8176.20\end{array}$

Prepared: $07 / 29 / 03$

-- End of Enclosures --

\section{REFERENCE GUIDE}

Column A: Identifies all awards for past and future damages.

Column B: The original itemized verdict

Column C: Represent the apportionment of the first $\$ 250,000$ by percent. According to Article 50A/50B the first $\$ 250,000$ of all future awards must be apportioned and paid to the plaintiff in a single lump sum.

Column D: The apportionment in actual dollars, which represents this $\$ 250,000$.

Column E: The adjusted verdict after deducting the $\$ 250,000$. This was arrived by deducting Column D from Column B

Column F: The years awarded.

Column G: The annualized benefit before deducting for attorney fees was calculated by dividing the adjusted verdict, Column E by the years awarded, Column F.

Column H: The present value was calculated on the annualized benefit (Column G) assuming the noted discount rates.

Column I: Attorney fees were calculated in accordance with the sliding scale.

Column J: The present value after deducting the attorney fees.

Column K: The cash lump sum award for past damages, less attorney fees and expenses.

Column L: The adjusted award after attorney fees is calculated by taking the adjusted verdict, Column $\mathrm{E}$ and reducing it by the ratio of (Sum of Column I)/(Sum of Column H)

Column M: Taking the Adjusted Award after Fees Column L, divided by the number of years awarded in Column F arrived at the Adjusted Annual Benefit after fees.

Column N: The Adjusted Monthly Benefit represents the Adjusted Annual Benefit in Column M divided by 12.

\section{ASSIGNMENT}

Review the expert's report for accuracy. This review is meant to determine both whether the present value analysis was done correctly as well as whether the proper interest rates were utilized. This review will require you to:

1. Reproduce the report's spreadsheet and make sure that all assumptions and calculations are correct. When assumptions are not clearly specified in the report, e.g. how to calculate the present value given a certain interest rate, then briefly explain (with illustrations) how it is done. In the event that your analysis results in different values than those given in the report's spreadsheet supply your new spreadsheet and explain what the differences are and why you think your values are correct. Make sure when you do this to comment about the plaintiff's lawyer second objection previously discussed. 
2. Look up the interest rates for government securities of different lengths of time at the time the verdict was rendered, December 17, 2002. Using all, some or a combination of these rates, develop a methodology to recalculate the spreadsheet in a manner that addresses the first objection of the plaintiff's lawyer. Does this change significantly alter the results? Make sure when you do this to comment on the plaintiff's lawyer first objection. Do you find anything in the law that agrees or refutes the lawyer's contention concerning the proper interest rate to use?

3. Discuss your impression of the entire methodology used to determine both plaintiff's and his attorney's compensation, i.e. Does adding $4 \%$ yearly to payouts for future damages make sense? Does it accurately reflect the jury's decision? In forming your answer to this question read and refer to the court's opinion in Samuel Desiderio v. Dr. Robert L. Ochs, and New York Hospital (rendered April 8, 2003).

4. If you think you have a better methodology for computing the necessary payout schedules present it. How does your solution compare with the one given in www.hiscockbarclay.com/pdf/tiplalert7-03.pdf?

5. On the $2^{\text {nd }}$ page of the expert's report, mention is made of the fact that the jury verdict was rendered December 17, 2002 but for whatever reason, actual payments were to actually commence September 17, 2003. According to New York State Law, all payments to the plaintiff must commence on the date that the verdict was rendered and if they are delayed plaintiff must be compensated for late payments at the rate of $9 \%$ a year. Calculate what you think should be the compensation due the plaintiff and his lawyer if payments commence on September 17, 2003. Do you agree with Rohing v. Niagara Falls (No. 117, June 30 1994) as to the way this should be calculated? 
Table 1

\begin{tabular}{|c|c|c|c|c|c|c|c|c|c|c|c|c|c|}
\hline A & $\mathrm{B}$ & C & $\mathrm{D}$ & $\mathrm{E}$ & $\mathrm{F}$ & $\mathrm{G}$ & $\mathrm{H}$ & I & $\mathrm{J}$ & $\mathrm{K}$ & $\mathrm{L}$ & $M$ & $\mathrm{~N}$ \\
\hline Damages & & $\begin{array}{c}\text { Apportionment } \\
\% \text { of Future }\end{array}$ & $\begin{array}{l}\text { Proportionate } \\
\text { Amt. of } \$ 250 \mathrm{k} \\
\end{array}$ & Adjusted & Award & $\begin{array}{c}\text { Annualized } \\
\text { Benefits }\end{array}$ & $\begin{array}{c}\text { Present } \\
\text { Value }\end{array}$ & $\begin{array}{l}\text { Attorneys } \\
\text { Fees }\end{array}$ & $\begin{array}{l}\text { Present Value } \\
\text { After Attorney }\end{array}$ & $\begin{array}{l}\text { Lump Sum } \\
\text { Award to }\end{array}$ & $\begin{array}{c}\text { Adjusted } \\
\text { Award After }\end{array}$ & $\begin{array}{l}\text { Adjusted } \\
\text { Annual } \\
\text { Award } \\
\end{array}$ & $\begin{array}{c}\text { Adjusted } \\
\text { Monthly } \\
\text { Award }\end{array}$ \\
\hline Barry Larke & Verdict & Damages & Deducted & Verdict & Years & Before fees & (a) & (b) & Fees & Plaintiff & Att. Fees ( c) & After fees & After fees (d) \\
\hline Pain \& Suffering & $\$ 300,000.00$ & & & $\$ 300,000.00$ & & & $\$ 300,000.00$ & $\$ 53,147.37$ & $\$ 246,852.63$ & & & & \\
\hline Loss of Earning & $\$ 350,000.00$ & & & $\$ 350,000.00$ & & & $\$ 350,000.00$ & $\$ 62,005.27$ & $\$ 287,994.73$ & & & & \\
\hline \multicolumn{2}{|c|}{ First 250k of Future Damages } & & & $\$ 250,000.00$ & & & $\$ 250,000.00$ & $\$ 44,289.48$ & $\$ 205,710.52$ & & & & \\
\hline Sub-Total & $\$ 650,000.00$ & & & $\$ 900,000.00$ & & & $\$ 900,000.00$ & $\$ 159,442.12$ & $\$ 740,557.88$ & $\$ 740,557.88$ & & & \\
\hline \multicolumn{14}{|l|}{ Future Damage } \\
\hline Pain \& Suffering & $\$ 600,000.00$ & $42.67 \%$ & $\$ 106,685.63$ & $\$ 493,314.37$ & 10 & $\$ 49,331.44$ & $\$ 477,852.68$ & $\$ 84,655.38$ & $\$ 393,197.30$ & & $\$ 405,919.83$ & $\$ 40,591.98$ & $\$ 3,382.67$ \\
\hline Loss of Earning & $\$ 806,000.00$ & $57.33 \%$ & $\$ 143,314.37$ & $\$ 662,685.63$ & 25 & $\$ 26,507.43$ & $\$ 566,212.44$ & $\$ 100,309.01$ & $\$ 465,903.43$ & & $\$ 545,285.63$ & $\$ 21,811.43$ & $\$ 1,817.62$ \\
\hline Sub-Total & $\$ 1,406,000.00$ & $100 \%$ & $\$ 250,000.00$ & $\$ 1,156,000.00$ & & & $\$ 1,044,065.12$ & $\$ 184,964.39$ & $\$ 859,100.73$ & & & & \\
\hline GrandTotal & $\$ 2,056,000.00$ & & & $\$ 2,056,000.00$ & & & $\$ 1,944,065.12$ & $\$ 344,406.51$ & $\$ 1,599,658.61$ & & & & \\
\hline
\end{tabular}

\footnotetext{
(a) PV was calculated using 4.10 for P\&S and 5.18 for loss of Earnings

(c) All awards reduced by 0.177157908 the ratio of Atty Fees and expenses divided by P.V.

(d) All monthly benefits compound annually at $4 \%$ in accordance with $50 \mathrm{~A}$
} 


\section{Document 1}

\section{NY STATE STATUTE}

ARTICLE 50-A PERIODIC PAYMENT OF JUDGMENTS IN MEDICAL AND DENTAL MALPRACTICE ACTIONS 5031. Basis for determining judgment to be entered. 5032. Form of security. 5033. Posting and maintaining security. 5034. Failure to make payment. 5035. Effect of death of judgment creditor. 5036. Adjustment of payments. 5037. Settlements. 5038. Assignment of periodic installments. 5039. Duties of superintendent of insurance. S 5031. Basis for determining judgment to be entered. In order to determine what judgment is to be entered on a verdict in an action to recover damages for dental, medical or podiatric malpractice under this article, the court shall proceed as follows: (a) The court shall apply to the findings of past and future damages any applicable rules of law, including set-offs, credits, comparative negligence pursuant to section fourteen hundred eleven of this chapter, additurs, and remittiturs, in calculating the respective amounts of past and future damages claimants are entitled to recover and defendants are obligated to pay. (b) The court shall enter judgment in lump sum for past damages, for future damages not in excess of two hundred fifty thousand dollars, and for any damages, fees or costs payable in lump sum or otherwise under subdivisions (c) and (d) of this section. For the purposes of this section, any lump sum payment of a portion of future damages shall be deemed to include the elements of future damages in the same proportion as such elements comprise of the total award for future damages as determined by the trier of fact. (c) Payment of litigation expenses and that portion of the attorney`s fees related to past damages shall be payable in a lump sum. Payment of that portion of the attorney`s fees related to future damages for which, pursuant to this article, the claimant is entitled to a lump sum payment shall also be payable in a lump sum. Payment of that portion of the attorney`s fees related to the future periodically paid damages shall also be payable in a lump sum, based on the present value of the annuity contract purchased to provide payment of such future periodically paid damages pursuant to subdivision (e) of this section. (d) Upon election of a subrogee or a lien holder, including an employer or insurer who provides workers` compensation, filed within the time permitted by rule of court, any part of future damages allocable to reimbursement of payments previously made by the subrogee or the lien holder shall be paid in lump sum to the subrogee or the lien holder in such amount as is calculable and determinable under the law in effect at the time of such payment. (e) With respect to awards of future damages in excess of two hundred fifty thousand dollars in an action to recover damages for dental, medical or podiatric malpractice, the court shall enter judgment as follows: After making any adjustments prescribed by subdivisions (b), (c) and (d) of this section, the court shall enter a judgment for the amount of the present value of an annuity contract that will provide for the payment of the remaining amounts of future damages in periodic installments. The present value of such contract shall be determined in accordance with generally accepted actuarial practices by applying the discount rate in effect at the time of the award to the full amount of the remaining future damages, as calculated pursuant to this subdivision. The period of time over which such periodic payments shall be made and the period of time used to calculate the present value of the annuity contract shall be the period of years determined by the trier of fact in arriving at the itemized verdict; provided, however, that the period of time over which such periodic payments shall be made and the period of time used to calculate the present value for damages attributable to pain and suffering shall be ten years or the period of time determined by the trier of fact, whichever is less. The court, as part of its judgment, shall direct that the defendants and their insurance carriers shall be required to offer and to guarantee the purchase and payment of such an annuity contract. Such annuity contract shall provide for the payment of the annual payments of such remaining future damages over the period of time determined pursuant to this subdivision. The annual payment for the first year shall be calculated by dividing the remaining amount of future damages by the number of years over which such payments shall be made and the payment due in each succeeding year shall be computed by adding four percent to the previous year`s payment. Where payment of a portion of the future damages terminates in accordance with the provisions of this article, the four percent added payment shall be based only upon that portion of the damages that remains subject to continued payment. Unless otherwise agreed, the annual sum so arrived at shall be paid in equal monthly installments and in advance. (f) With the consent of the claimant and any party liable, in whole or in part, for the judgment, the court shall enter judgment for the amount found for future damages attributable to said party as such are determinable without regard to the provisions of this article. S 5032. Form of security. Security authorized or required for payment of a judgment for periodic installments entered in accordance with this article must be in the form of an annuity contract, executed by a qualified insurer and approved by the superintendent of insurance pursuant to section five thousand thirty-nine of this article, and approved by the 
court. S 5033. Posting and maintaining security. (a) If the court enters a judgment for periodic installments, each party liable for all or a portion of such judgment shall separately or jointly with one or more others post security in an amount necessary to secure payment for the amount of the judgment for future periodic installments within thirty days after the date the judgment is entered. A liability insurer having a contractual obligation and any other person adjudged to have an obligation to pay all or part of a judgment for periodic installments on behalf of a judgment debtor is obligated to post security to the extent of its contractual or adjudged obligation if the judgment debtor has not done so. (b) A judgment creditor or successor in interest and any party having rights may move that the court find that security has not been posted and maintained with regard to a judgment obligation owing to the moving party. Upon so finding, the court shall order that security complying with this article be posted within thirty days. If security is not posted within that time and subdivision (c) of this section does not apply, the court shall enter a judgment for the lump sum as such sum is determinable under the law without regard to this article. (c) If a judgment debtor who is the only person liable for a portion of a judgment for periodic installments fails to post and maintain security, the right to lump sum payment described in subdivision (b) of this section applies only against that judgment debtor and the portion of the judgment so owed. (d) If more than one party is liable for all or a portion of a judgment requiring security under this article and the required security is posted by one or more but fewer than all of the parties liable, the security requirements are satisfied and those posting security may proceed under subdivision (b) of this section to enforce rights for security or lump sum payment to satisfy or protect rights of reimbursement from a party not posting security. S 5034. Failure to make payment. If at any time following entry of judgment, a judgment debtor fails for any reason to make a payment in a timely fashion according to the terms of this article, the judgment creditor may petition the court which rendered the original judgment for an order requiring payment by the judgment debtor of the outstanding payments in a lump sum. In calculating the amount of the lump sum judgment, the court shall total the remaining periodic payments due and owing to the judgment creditor, as calculated pursuant to subdivision (e) of section five thousand thirty-one of this article, and shall not convert these amounts to their present value. The court may also require the payment of interest on the outstanding judgment. S 5035. Effect of death of judgment creditor. (a) Unless otherwise agreed between the parties at the time security is posted pursuant to section five thousand thirty-three of this article, in all cases covered by this article in which future damages are payable in periodic installments, the liability for payment of any installments for medical, dental or other costs of health care or noneconomic loss not yet due at the death of the judgment creditor terminates upon the death of the judgment creditor. (b) The portion of any periodic payment allocable to loss of future earnings shall not be reduced or terminated by reason of the death of the judgment creditor, but shall be paid to persons to whom the judgment creditor owed a duty of support immediately prior to his death to the extent that such duty of support exists under applicable law at the time of the death of the judgment creditor. Such payments to such persons shall continue for the remainder of the period as originally found by the jury or until such duty of support ceases to exist, whichever occurs first. In such cases, the court which rendered the original judgment may, upon petition of any party in interest, modify the judgment to award and apportion the future payments of such unpaid future damages in accordance with this subdivision which apportioned amounts shall be payable in the future as provided for in this article. In the event that the judgment creditor does not owe a duty of support to any person at the time of the death of the judgment creditor or such duty ceases to exist, the remaining payments shall be considered part of the estate of the judgment creditor. In such cases, the court which rendered the original judgment may, upon petition of any party in interest, convert those portions of such periodic payments allocable to the loss of future earnings to a lump sum by calculating the present value of such payments in order to assist in the settlement of the estate of the judgment creditor. S 5036. Adjustment of payments. (a) If, at any time after entry of judgment, a judgment creditor or successor in interest can establish that the continued payment of the judgment in periodic installments will impose a hardship, the court may, in its discretion, order that the remaining payments or a portion thereof shall be made to the judgment creditor in a lump sum. The court shall, before entering such an order, find that: (i) unanticipated and substantial medical, dental or other needs have arisen that warrant the payment of the remaining payments, or a portion thereof, in a lump sum; (ii) ordering such a lump sum payment would not impose an unreasonable financial burden on the judgment debtor or debtors; (iii) ordering such a lump sum payment will accommodate the future medical and other needs of the judgment creditor; and (iv) ordering such a lump sum payment would further the interests of justice. (b) If a lump sum payment is ordered by the court, such payment shall be made by the medical malpractice insurance association created pursuant to article fifty-five of the insurance law and shall not be the obligation of the insurer providing the initial annuity contract. Such insurer shall thereafter make all future payments due under its annuity contract to the association, except that, if the lump sum payment ordered by the court is a 
portion of the remaining periodic payments, such insurer shall appropriately apportion future payments due under its annuity contract between the association and the judgment creditor or successor in interest. Such lump sum payment to be paid to the judgment creditor or successor in interest by the association shall be calculated on the basis of the present value of the annuity contract, which shall be based on its cost at such time, for remaining periodic payments, or portions thereof, that are converted into a lump sum payment. In no event shall such lump sum payment be greater than the present value of the annuity contract for the remaining periodic payments. S 5037. Settlements. Nothing in this article shall be construed to limit the right of a plaintiff, defendant or defendants and any insurer to settle dental, medical or podiatric malpractice claims as they consider appropriate and in their complete discretion. $\mathrm{S}$ 5038. Assignment of periodic installments. An assignment of or an agreement to assign any right to periodic installments for future damages contained in a judgment entered under this article is enforceable only as to amounts: (a) to secure payment of alimony, maintenance, or child support; (b) for the cost of products, services, or accommodations provided or to be provided by the assignee for medical, dental or other health care; or (c) for attorney`s fees and other expenses of litigation incurred in securing the judgment. S 5039. Duties of superintendent of insurance. The superintendent of insurance shall establish rules and procedures for determining which insurers, self-insurers, plans or arrangements are financially qualified to provide the security required under this article and to be designated as qualified insurers.

Notes 